\title{
Risk of a syndemic between COVID-19 and dengue fever in southern Mexico
}

\author{
Juan P. Sánchez-de la Cruz, ${ }^{1}$ Carlos A. Tovilla-Zárate, ${ }^{1 *}$ Diana L. González-Morales ${ }^{1}$ and \\ Thelma B. González-Castro² \\ ${ }^{1}$ Comalcalco Multidisciplinary Academic Division; 2 Jalpa de Méndez Multidisciplinary Academic Division, Universidad Juárez Autónoma de Tabasco, \\ Tabasco, Mexico
}

\begin{abstract}
A syndemic is the convergence of two or more diseases in the same space and time. In Mexico, the dengue epidemic is active and predominates in areas of the Pacific and the Gulf of Mexico; in turn, the COVID-19 epidemic severely affects the same areas as dengue fever. Given that both these diseases share many clinical manifestations, in areas where tropical diseases are endemic, it is important to make careful evaluations of the patient who consults for fever in order to establish a timely diagnosis. Laboratory diagnostic tests are necessary to take the pertinent measures for each patient. In Mexico, the risk of a syndemic between COVID-19 and dengue fever is high, and thus it that can collapse health systems. The states of southeastern Mexico and the Pacific region require special attention, since they have geographic, environmental and climatic conditions that favor the rapid spread of dengue and COVID-19. Simultaneous infection will worsen the epidemiological situation, and complicate the diagnosis, control and treatment of both diseases.
\end{abstract}

KEY WORDS: Syndemic. COVID-19. Dengue. Gulf of Mexico. Epidemic.

\section{Riesgo de sindemia de COVID-19 y fiebre del dengue en el sur de México}

\section{Resumen}

Una sindemia es la convergencia de dos o más enfermedades en un mismo espacio y tiempo. En México, la epidemia de dengue está activa y predomina en zonas del Pacífico y Golfo de México; por su parte, la epidemia de COVID-19 afecta severamente las mismas zonas que el dengue. Dado que estas enfermedades comparten numerosas manifestaciones clínicas, en zonas endémicas de enfermedades tropicales es importante la evaluación minuciosa del paciente que consulta por fiebre, para establecer oportunamente un diagnóstico correcto. Las pruebas de laboratorio son necesarias para llevar a cabo las medidas pertinentes en cada paciente. En México, el riesgo de sindemia de COVID-19 y dengue es alto, por lo que puede colapsar los sistemas de salud. Los estados del sureste y los colindantes con el Pacífico requieren especial atención ya que presentan condiciones geográficas, ambientales y climáticas que favorecen la rápida propagación del dengue y COVID-19. La infección simultánea empeorará la situación epidemiológica, complicará el diagnóstico, control y tratamiento de ambas enfermedades.

PALABRAS CLAVE: Sindemia. COVID-19. Dengue. Golfo de México. Epidemia.

Correspondence:

${ }^{*}$ Carlos A. Tovilla-Zárate

E-mail: alfonso_tovillaz@yahoo.com.mx
Gac Med Mex. 2020;156:460-464

Contents available at PubMed

www.gacetamedicademexico.com 0016-3813/@ 2020 Academia Nacional de Medicina de México, A.C.. Published by Permanyer. This is an open access article under the CC BY-NC-ND license (http://creativecommons.org/licenses/by-nc-nd/4.0/). 


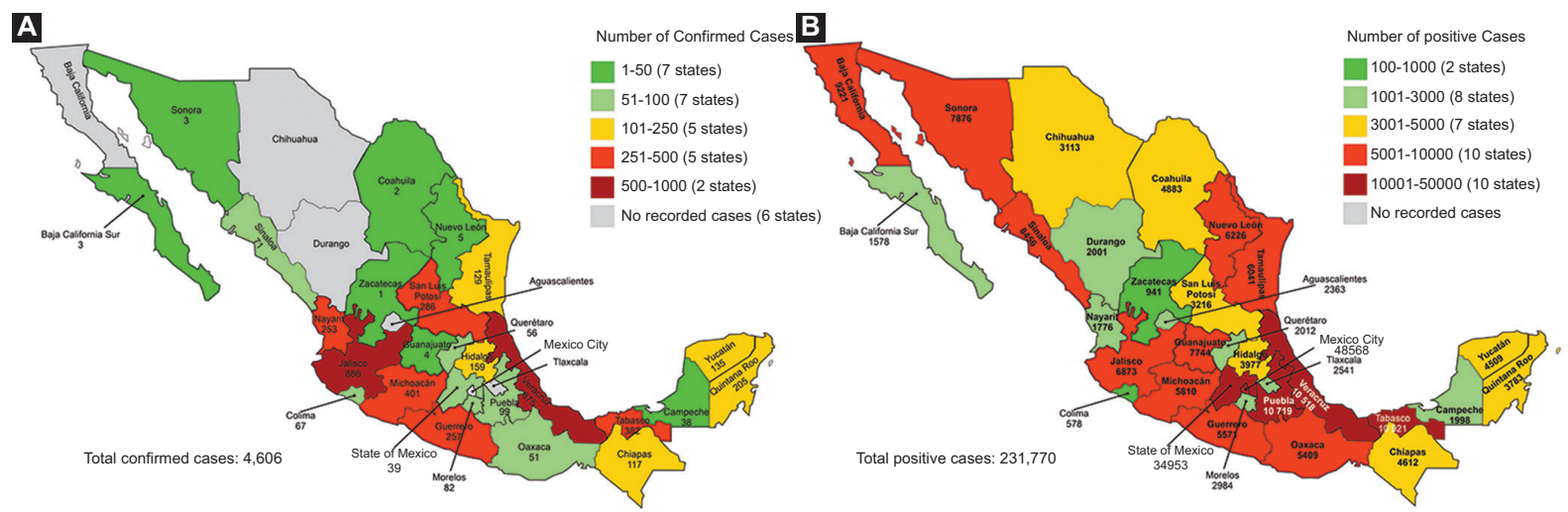

Figure 1. Epidemiological map of Mexico per state by July 1, 2020. A) Total dengue fever cases. B) Total COVID-19 cases.

\section{Introduction}

A syndemic is defined as the convergence of two or more diseases that share social and environmental factors the interaction of which causes negative effects to the affected population and increases the burden of disease. ${ }^{1,2}$ Infectious diseases have a high potential for producing a syndemic behavior, ${ }^{2}$ as well as emerging infectious diseases, which can cause a syndemic with the endemic diseases of a population. ${ }^{3,4}$

One of the main epidemics that has affected different regions of the world in recent years is dengue fever, ${ }^{5-7}$ caused by all four dengue flavivirus serotypes (DENV-1 to DENV-4). ${ }^{8}$ The spread of dengue depends on two vector mosquitoes: Aedes aegypti and Aedes albopictus. ${ }^{8}$ The incidence of this disease is high around the world, mainly in countries of the Western Pacific, Southeast Asia and South America, where it constitutes an endemic disease in these regions. ${ }^{5,6}$ The incidence of dengue fever is estimated to range from 100 to 400 million cases per year, and it has drastically grown and affects all regions of the world. ${ }^{9}$ In 2019, the region of the Americas reported 3.1 million cases, which represented a significant incidence increase in comparison with 2.38 million cases in $2016 .^{9}$

In Mexico, the incidence has also increased in recent decades, with a predominance in the Pacific and Gulf of Mexico regions. ${ }^{10,11}$ In addition, a higher incidence was identified during the second semester of the year, with peaks in the months of September and October. ${ }^{10}$ In 2019, 41,505 dengue fever cases and 191 deaths were confirmed, with an additional 268,458 suspected cases that were not confirmed, ${ }^{12}$ which means that for every confirmed case there are 6.4 unconfirmed cases. At the same time, the Ministry of Health reported that $69 \%$ of cases were confirmed in five states located at the Gulf of Mexico and Pacific regions (Jalisco, Veracruz, Chiapas, Quintana Roo and Oaxaca). The dengue epidemic is active in Mexico, and for 2020 epidemiological week 26 , there were 4,606 confirmed cases, (which is a figure that can be six times higher) (Fig. 1A). In the same epidemiological week of 2019, the figure was 3,599 cases..$^{13}$ So far, in 2020 , the most affected states are Jalisco, Veracruz, Michoacán, Tabasco and San Luis Potosí, which concentrate $61 \%$ of the cases. In Mexico, the incidence of dengue until June 2020 was 3.62 cases per 100,000 population.

On the other hand, the pandemic caused by the SARS-CoV-2 virus, a coronavirus that causes COVID-19, became a global health crisis. ${ }^{14}$ The disease that emerged in Wuhan, China, by the end of $2019,{ }^{15}$ has caused the infection of more than 10 million people worldwide and caused the death of more than 500 thousand people by the end of June $2020 . .^{16}$ In Mexico, on July 1, 2020, 231,770 confirmed cases of COVID-1917 had been reported (Fig. 1B), with an incidence of 181.36 cases per 100,000 population (Table 1)..$^{18}$ The most affected states according to the number of confirmed cases are Mexico City $(48,568)$, followed by the State of Mexico $(34,953)$, Tabasco $(10,921)$, Puebla $(10,719)$ and Veracruz $(10,518) \cdot{ }^{17}$

\section{Risk of a syndemic in Mexico}

Countries with a high incidence of dengue fever have expressed concern about the high probability of 
Table 1. Incidence of dengue fever and COVID-19 in Mexico, distribution per state by July 1, 2020.

\begin{tabular}{|c|c|c|}
\hline \multirow[t]{2}{*}{ State } & \multicolumn{2}{|c|}{ Incidence } \\
\hline & Dengue & COVID-19 \\
\hline National mean & 3.62 & 181.36 \\
\hline Aguascalientes & 0.00 & 164.71 \\
\hline Baja California & 0.00 & 253.68 \\
\hline Baja California Sur & 0.34 & 196.1 \\
\hline Campeche & 3.90 & 199.68 \\
\hline Chihuahua & 0.00 & 81.86 \\
\hline Chiapas & 2.10 & 80.48 \\
\hline Mexico City & 0.00 & 538.53 \\
\hline Coahuila & 0.06 & 151.71 \\
\hline Colima & 8.56 & 73.62 \\
\hline Durango & 0.00 & 107.06 \\
\hline State of Mexico & 0.22 & 200.56 \\
\hline Guanajuato & 0.07 & 124.34 \\
\hline Guerrero & 7.03 & 152.34 \\
\hline Hidalgo & 5.22 & 128.86 \\
\hline Jalisco & 10.59 & 77.26 \\
\hline Michoacán & 8.46 & 120.4 \\
\hline Morelos & 4.04 & 145.98 \\
\hline Nayarit & 18.97 & 137.83 \\
\hline Nuevo León & 0.09 & 110.98 \\
\hline Oaxaca & 1.24 & 130.54 \\
\hline Puebla & 1.53 & 162.3 \\
\hline Queretaro & 2.61 & 88.26 \\
\hline Quintana Roo & 11.40 & 219.53 \\
\hline Sinaloa & 2.29 & 267.88 \\
\hline San Luis Potosí & 9.97 & 112.21 \\
\hline Sonora & 0.10 & 256.15 \\
\hline Tabasco & 15.29 & 424.56 \\
\hline Tamaulipas & 3.45 & 165.48 \\
\hline Tlaxcala & 0.00 & 184.13 \\
\hline Veracruz & 10.51 & 123.16 \\
\hline Yucatan & 5.99 & 199.59 \\
\hline Zacatecas & 0.06 & 56.97 \\
\hline
\end{tabular}

a syndemic with COVID-19 and the risk this implies for their health systems..$^{19-21}$ These are countries with tropical areas and that still have not controlled the COVID-19 epidemic; having to deal with such a situation would generate a negative impact on public health. ${ }^{19}$ Latin America, current epicenter of the COVID-19 pandemic, ${ }^{22,23}$ has a high incidence of dengue and has the climatic and environmental conditions for suffering a syndemic. The situation in Mexico regarding the risk of a syndemic between dengue and COVID-19 is very similar to that of other Latin American countries.

The COVID-19 epidemic is also active in the Mexican territory and continues to increase; in areas with larger amounts of rainfall and a temperate climate, conditions are favorable for an increase in the number of dengue cases. ${ }^{24}$ Priority attention is required by the states of southeastern Mexico and the Pacific region, since they have exceptional conditions for dengue rapid spread; the growing COVID-19 epidemic in these areas might cause serious effects on public health. For this reason, patients in these regions consulting for fever should be treated with priority.

The southeastern region of Mexico is a tropical zone with climatological and environmental characteristics that are similar to those of South America. Rainfall in this area is higher than in other regions of the country, and rainy conditions, hot-humid climate and higher environmental temperature have been shown to favor dengue transmission. ${ }^{25}$ The Gulf of Mexico states exhibit high numbers of COVID-19 cases, and are also the states with the highest number of dengue fever cases (Fig. 1). The states with the highest risk in this area are Veracruz, Tabasco, Quintana Roo, Yucatán and Tamaulipas. In the Pacific coast, the states with the highest risk of a syndemic are Jalisco, Michoacán and Guerrero. In isolation, the state of San Luis Potosí has a high health risk, since dengue has remained at epidemic figures throughout 2020, although this state is not considered an endemic dengue area. Incidence rates for both diseases are also high in the same regions (Table 1).

Prevention measures for both COVID-19 and dengue should be enhanced in the states of the Gulf of Mexico and the Pacific coast. One of the strategies to reduce the incidence of dengue is fumigation; however, some populations have adopted the false belief that fumigation favors the spread of the SARS-CoV-2 virus and do not allow health 
authorities to fumigate, thus increasing the risk for a syndemic.

Finally, COVID-19 and dengue fever are diseases that manifest themselves with fever, headache and general malaise; therefore, patients who consult with mild symptoms without further clinical data are at risk of being misdiagnosed. The clinical manifestations that both diseases share can complicate the diagnosis if specific laboratory tests are not available.

\section{Conclusions}

Diagnosing a patient who consults for fever can become a challenge according to the geographic region; initially distinguishing between dengue fever and COVID-19 can be more difficult if the latter does not exhibit the typical respiratory symptoms. Both conditions have similar clinical manifestations, such as headache, myalgia, arthralgia, asthenia, adynamia and general malaise. In the context of tropical diseases' endemic areas, it is important to make careful evaluations of the patient who consults for fever in order to establish a timely diagnosis. Diagnostic laboratory tests are necessary, given that COVID-19 late detection favors its spread. The lack of dengue or COVID-19 timely diagnosis has serious implications both for the patient, who does not receive adequate treatment or the necessary care, and for the health system, which does not apply the necessary health and preventive measures. Owing to the contagiousness of COVID-19, it is important not to delay the diagnosis and putting the patient in isolation; in contrast, dengue fever is transmitted by a vector and home isolation is not necessary.

Regarding the care of both diseases, it is important mentioning that they can cause serious complications, mainly in patients with chronic conditions. In particular, simultaneous infection with COVID-19 and dengue in a single patient can complicate the health status, increase the need for hospitalization, and even admission to the intensive care unit. If this occurs hastily, it will be necessary to create care protocols that include therapeutic and pharmacological measures for these patients, as well as to adapt hospitals in order to increase availability of beds in intensive care units. Simultaneous infection will worsen the epidemiological situation, and complicate the diagnosis, control and treatment. Given the geographical, environmental and climatic conditions of southern
Mexico, this risk is higher in comparison with other regions of the country.

\section{Conflict of interests}

The authors declare that they have no conflicts of interest.

\section{Funding}

The authors did not receive any funding for carrying out this article.

\section{Ethical disclosures}

Protection of human and animal subjects. The authors declare that no experiments were performed on humans or animals for this research.

Confidentiality of data. The authors declare that no patient data appear in this article.

Right to privacy and informed consent. The authors declare that no patient data appear in this article.

\section{References}

1. Singer M, Bulled N, Ostrach B, et al. Syndemics and the biosocial conception of health. Lancet. 2017;389:941-50.

2. Kwan CK, Ernst JD. HIV and tuberculosis: a deadly human syndemic. Clinical microbiology reviews. 2011:24:351-376.

3. Singer M. The spread of Zika and the potential for global arbovirus syndemics. Global Public Health. 2017;12:1-18.

4. Carlson CJ, Mendenhall E. Preparing for emerging infections means expecting new syndemics. Lancet. 2019;394:297.

5. Kraemer MU, Sinka ME, Duda KA, et al. The global distribution of the arbovirus vectors Aedes aegypti and Ae. albopictus. Elife. 2015;4:e08347.

6. Pan CY, Liu WL, Su MP, et al. Epidemiological analysis of the Kaohsiung city strategy for dengue fever quarantine and epidemic prevention. BMC Infectious Diseases. 2020;20:1-9.

7. Mamun MA, Misti JM, Griffiths MD, Gozal D, et al. The dengue epidemic in Bangladesh: risk factors and actionable items. Lancet. 2019;394:21492150.

8. Ali H, Alvi A, Fatima S, et al. Dengue fever in Pakistan, episodes of epidemic to endemic: Treatment challenges, prevention and current facts. J Bioequiv Availab. 2017;9:473-476.

9. World Health Organization [Internet]. Switzerland: Dengue and severe dengue; 2020.

10. Torres-Galicia I, Cortés-Poza D, Becker I. Dengue en México: análisis de dos décadas. Gac Med Mex. 2014;150:122-127.

11. Fajardo-Dolci G, Meljem-Moctezuma J, Vicente-González E, Venegas-Páez FV, Mazón-González B, Aguirre-Gas HG. El dengue en México. Conocer para mejorar la calidad de la atención. Rev Med Inst Mex Seguro Soc. 2012;50:631-639.

12. Secretaría de Salud [Internet. Mexico: Panorama epidemiológico de dengue 2019-2020; 2020.

13. Secretaría de Salud [Internet]. Mexico: Panorama epidemiológico de dengue 2020; 2020.

14. Guo YR, Cao QD, Hong ZS, Tan YY, Chen SD, Jin HJ, et al. The origin, transmission and clinical therapies on coronavirus disease 2019 (COVID-19) outbreak - An update on the status. Mil Med Res. 2020;7:11.

15. Zhu N, Zhang D, Wang W, Li X, Yang B, Zhao X, et al. A novel coronavirus from patients with pneumonia in China, 2019. N Engl J Med. 2020;382:727-733.

16. Johns Hopkins University [Internet]. USA: COVID-19 Map 2020; 2020

17. Secretaría de Salud [Internet]. Mexico: COVID-19, datos epidemiológicos; 2020. 
18. Secretaría de Salud [Internet]. Mexico: COVID-19, Tasa de incidencia de casos acumulados por entidad federativa de residencia 2020; 2020

19. Haqqi A, Awan UA, Ali M, Arif M, Ahmed H, Sohail M. COVID-19 and dengue virus co-epidemics in Pakistan: A dangerous combination for an overburdened healthcare system. J Med Virol; 2020.

20. Lam LTM, Chua YX, Tan DHY. Roles and challenges of primary care physicians facing a dual outbreak of COVID-19 and dengue in Singapore. Fam Pract. 2020:cmaa047.

21. Lorenz C, Azevedo TS, Chiaravalloti-Neto F. COVID-19 and dengue fever: A dangerous combination for the health system in Brazil. Trave Med Infect Dis. 2020;35:101659.
22. Horton J. Coronavirus: What are the numbers out of Latin America? United Kingdom: BBC News; 2020.

23. Pan American Health Organization [Internet]. USA: PAHO Director says fight against COVID-19 pandemic must include chronic disease care 2020; 2020.

24. Ordóñez-Sierra R, Gómez-Albores MA, Mastachi-Loza CA, Díaz-Delgado C, Manzano-Solís R, Medina-Torres I, et al. Análisis del cambio en las condiciones climáticas y su relación con casos de dengue en la parte centro de México. Digital Ciencia @ UAQRO. 2019;12:96-105.

25. Siregar FA, Makmur T. Climate risks and environmental determinants on dengue transmission. Indian J Public Health Res Dev. 2019;10(1):1242-1247. 